\title{
A New Species of Spongilla (Porifera, Demospongiae) from a Karst Lake in Ha Long Bay (Vietnam)
}

\author{
Barbara Calcinai ${ }^{1, *}{ }^{\oplus}$, Carlo Cerrano ${ }^{1,2}{ }^{\oplus}$, Laura Núñez-Pons ${ }^{2}(0)$, Maurizio Pansini ${ }^{3}$, \\ Do Cong Thung ${ }^{4}$ and Marco Bertolino ${ }^{3}$ (D) \\ 1 Department of Life and Environmental Sciences, Università Politecnica delle Marche, 60131 Ancona, Italy; \\ c.cerrano@univpm.it \\ 2 Department of Integrated Marine Ecology (EMI), Stazione Zoologica Anton Dohrn (SZN), 80121 Napoli, \\ Italy; laura.nunezpons@szn.it \\ 3 Department of Earth, Environmental and Life Sciences, University of Genova, 16132 Genova, Italy; \\ pansisml@gmail.com (M.P.); marco.bertolino@edu.unige.it (M.B.) \\ 4 Institute of Marine Environment and Resources (IMER), Hai Phong City, Vietnam; thungdocong@gmail.com \\ * Correspondence: b.calcinai@univpm.it; Tel.: +39-071-2204283
}

Received: 26 October 2020; Accepted: 5 December 2020; Published: 9 December 2020

\begin{abstract}
Cahong in Ha Long Bay (Vietnam) is a small lake with a reduced, invisible connection with the open sea. The water column conditions locally experience notable fluctuations across the year, mostly driven by biannual monsoon seasons. Salinity, temperature, and $\mathrm{pH}$ often reach extreme values, unsustainable for the majority of the marine fauna. Therefore, the biodiversity of the benthic macrofauna in this peculiar habitat is remarkably low. In particular, a single sponge species new to science was found solely populating this characteristic brackish lake during our last survey in August 2018. Spongilla manconiae sp. nov. is a new Porifera species described here. It belongs to an exclusively freshwater taxon and seems to have acquired adaptive traits to tolerate extreme peaks of temperature and salinity. The mitochondrial Cytochrome C Oxidase subunit 1 (COI) and the nuclear Internal Transcribed Spacers 1 and 2 (ITSs) gene markers were used for barcoding tagging and phylogenetic analyses. The new species revealed large genetic distances and separate clustering in the tree topology, with respect to other reference spongillid sequences from various geographic areas. The study provides evidence for an urgency to protect these unique marine lake systems because they represent rare, fluctuant, fragile habitats that may speed up speciation processes.
\end{abstract}

Keywords: Porifera; freshwater sponge; new species; karstification; Cat Ba Archipelago

\section{Introduction}

Cat Ba Archipelago_-in Ha Long Bay (North-Eastern Vietnam)—is characterized by thousands of karst towers and islands dating back to the Tertiary Period (about 35 mya). Karst processes have induced the formation of numerous sea lakes [1]. Besides Vietnam, in the Indo-Pacific area, analogous marine lakes are found in Indonesia and Palau. Recent reports from Vermeulen et al. [2] registered 138 sea lakes in Ha Long Bay, which correspond to about 1/3 of the 400 estimated saltwater lakes existing all over the world.

Marine lakes are unique habitats characterized by brackish to marine water, according to their degree of connection with the open sea, which can be secluded or visible [3]. In Vietnam, the physical-chemical characteristics of the more cloistered marine lakes are for the most part extreme and regulated by intense fluctuations of temperature and rainfall. During the monsoon season occurring in late spring and summer, high temperatures and heavy rains cause severe stratification in the water column. Under such extreme conditions, a large portion of the marine fauna in the lakes 
partly degenerates or totally disappear [3]. Highly isolated lakes, such as the large marine Kakaban lake in Indonesia, are known to host a high number of endemic species of several marine taxa [4] and are consequently optimal scenarios for rapid evolution and speciation processes [5].

Sponges are elemental components of the marine benthic fauna from tropical, temperate to polar regions [6-9], acting as ecosystem engineers and performing key ecological roles [10,11]. The sponge fauna of Vietnam has been moderately studied, with 299 demosponges (201 identified at species level) reported up to 2013 [12,13]. In the frame of international projects with Vietnam, some of the present authors recorded during several expeditions 46 species in nine surveyed marine karst lakes of Ha Long Bay [12,14]; 23 of these are exclusive of such lake environment. Recently, Cerrano and co-workers [15] noticed three new sponge species never recorded before in Vietnam and updated the inventory to 302. However, according to the last monitoring surveys, the sponge diversity in the area appears to be drastically decreasing since more than half the species reported until 2007 were not recorded again [15]. This paper provides the description of a sponge species new to science coming from an enclosed marine karst lake, with the additional aim to increase awareness toward the singularity of these rare, fragile, and threatened habitats, and encourage their protection.

\section{Materials and Methods}

\subsection{Sampling Site and Sponge Collection}

The survey was conducted in August 2018 in Cahong lake (Ha Long Bay) in the frame of the cooperative project "Studying biodiversity of limestone islands in Vietnam's waters; proposing solutions and models to use, conserve, and sustainably develop" (codes KC09.11/16-20), involving the Polytechnic University of Marche, the University of Genoa, and the Institute of Marine Environment and Resources (IMER) of Hai Phong. Cahong lake is an enclosed lake with no evident connection with the open water. It is one of the numerous karstic saltwater lakes of Ha Long Bay, whose formation goes back to the last glaciation period (c. $18000 \mathrm{yr}$ BP) [16]. This isolated lake is located inside the small island of Congdo $\left(20^{\circ} 52^{\prime} 46^{\prime \prime} \mathrm{N}-107^{\circ} 12^{\prime} 12^{\prime \prime}\right.$ E) (Figure 1). This lake has been identified after interviewing local fishermen, exploiting a Local Ecological Knowledge (LEK) approach. Fishermen told us that the lake is among those frequently visited and occasionally exploited as a natural fishing pond for promoting fish farming. The physical-chemical characteristics of the superficial layer of the lake were measured in December 2017 and August 2019 by the staff of the Hai Phong Institute using a multifunctional environment meter (model WQC-24).

Sponge collection was qualitative. Seven samples were collected by SCUBA diving, following visually oriented transects, spaced about $5 \mathrm{~m}$ from one another to cover a significant area of the lake. The maximum depth in the lake was $6 \mathrm{~m}$; however, our sampling went down to $3 \mathrm{~m}$, where the limit of sponge life seemed to be established. Following reference [17], below this depth, the temperature recorded by the dive computer (Ratio, iDive Easy) was very high, around $38^{\circ} \mathrm{C}$ and there were no signs of living organisms. The only sponge species found in the lake was the one reported here. This peculiar vertical distribution of environmental parameters reminds of solar ponds, rarely reported as natural systems. A solar pond is a body of a certain liquid, relatively shallow and generally artificial that maintains a downward positive density gradient and thereby entraps heat in bottom layers. Such a density gradient counteracts the change of density induced by the absorption of solar radiation, creating denser and warmer waters, which challenge the development of life toward the deeper layers. The sponges were photographed in situ and fresh on board. Specimens were divided into subsamples (about $3 \mathrm{~cm}^{3}$ ) and fixed in ethanol 70\% for morphological observations and in $4 \%$ formaldehyde solution for histological analyses; smaller portions $(\sim 1.5 \mathrm{~cm})$ were preserved in absolute ethanol at $4{ }^{\circ} \mathrm{C}$ for DNA barcoding. 


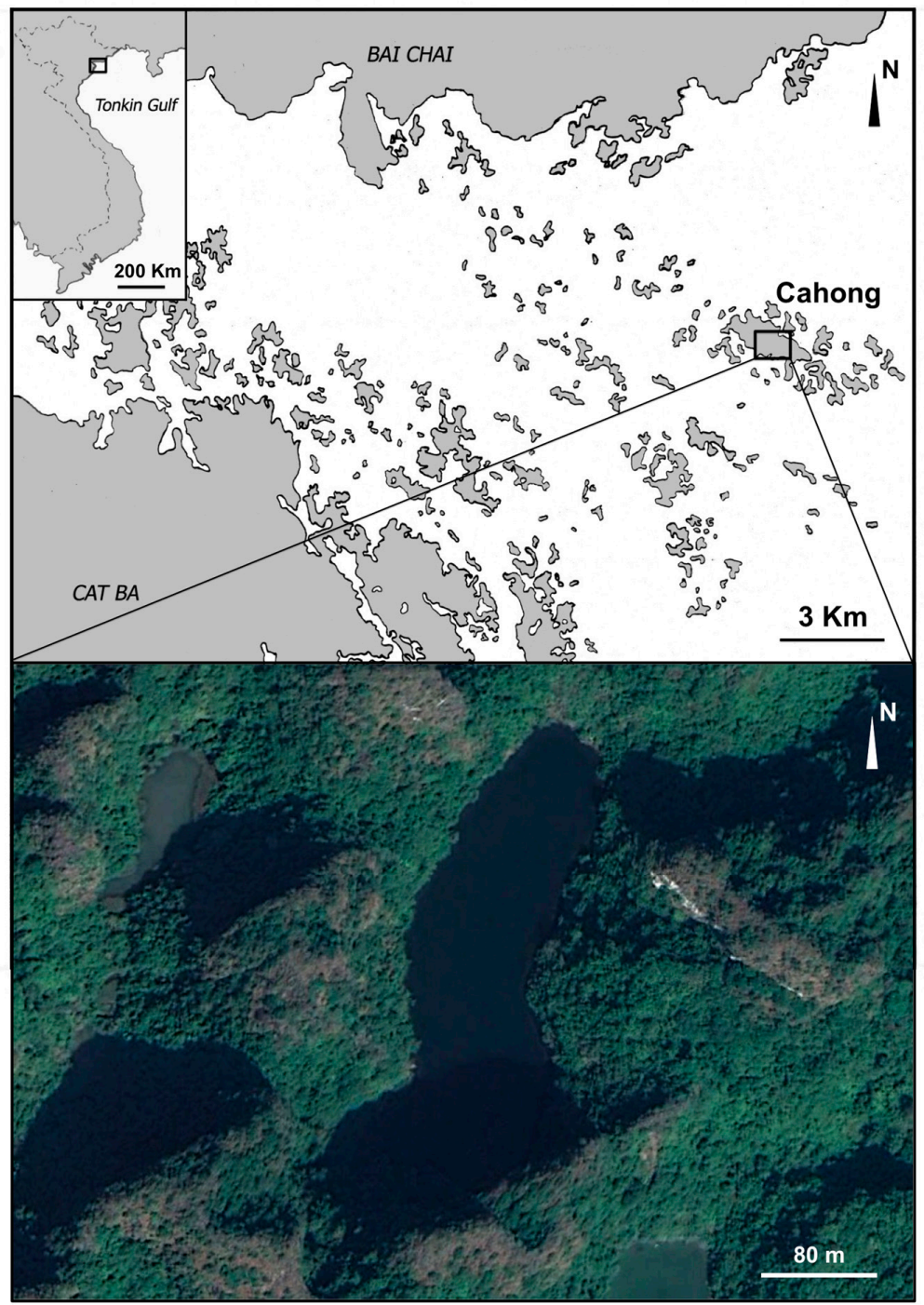

Figure 1. Map of the sampling site. The image below illustrates the Cahong lake.

\subsection{Morphological Study}

The material for the study of spicule morphometry and the skeletal organization was prepared following Rützler [18] and observed under light microscopy. Dissociated spicules were transferred onto stubs and coated with gold for SEM analyses (Philips XL 20 and Vega3_TESCAN Microscope type LMU). The skeletal architecture was studied by examining hand-cut sections of sponge portions, by SEM [19].

Spicule dimensions (obtained from 30 spicules) are given as the smallest length-(mean \pm SD)-largest length $\mathrm{x}$ smallest width-(mean \pm standard deviation)-largest width.

Type material was deposited at the Museo di Storia Naturale di Genova (MSNG), Italy.

\subsection{Genotyping}

Genomic DNA of sponge subsamples was purified using HiPura Soil DNA Purification Kit (HiMedia Laboratories, Mumbai, India) following manufacturer's protocols, and was stored at $-20^{\circ} \mathrm{C}$. Two gene marker regions were employed for barcoding. The mitochondrial Cytochrome $\mathrm{C}$ Oxidase subunit 1 (COI) was amplified using two pairs of primers. The standard COI partition $(\sim 640 \mathrm{bp})$ was amplified with the universal [20] dgHCO2198 (5'-GGTCAACAAATCATAAAGAYATYGG-3') and dgLCO1490 (TAAACTTCAGGGTGACCAAARAAYCA-3') primers. Additionally, the Erpenbeck's 
'I3-M11'extension of $\sim 560 \mathrm{bp}$, which overlaps $\sim 60$ bp with Folmer's 3' COI partition was amplified using the sponge specific primers PorCOI2fwd (5'-AATATGNGGGCNCCNGGNATNAC-3') and PorCOI2rev (5'-ACTGCCCCCATNGATAAAACAT-3') [21]. These two fragments were then concatenated with bioinformatic approaches (see below) to obtain a fragment of $\sim 1100 \mathrm{bp}$, which seems to improve taxonomic resolution in certain groups of Porifera and other diploblasts [22]. The nuclear ITSs fragment that included both Internal Transcribed Spacers 1 and 2, and covering 18S-ITS1-5.8S-ITS2-28S ( 850 bp) was amplified with the specific primer RA2 (5'-ACTGCCCC CATNGATAAAACAT- $3^{\prime}$ ) priming on the $3^{\prime}$ terminus of the $18 \mathrm{~S}$ small ribosomal subunit, and the ITS2.2 primer (5'-CCTGGTTAGTTTCTTTTCCTCCGC- $\left.3^{\prime}\right)$ targeting the $5^{\prime}$ terminus of the $28 \mathrm{~S}$ large ribosomal subunit [23]. A third fragment targeting the $28 \mathrm{~S}$ rDNA C-Region, recently included among the recommended taxonomic markers for Porifera [24], continuously failed in amplification trials and could not be sequenced for the present study. PCR amplifications were performed in $25 \mu \mathrm{L}$ volume reactions containing $2.5 \mu \mathrm{L}(2 \mathrm{mM})$ of Buffer, $1 \mu \mathrm{L}$ Deoxynucleotide (dNTP) solution mix $(2 \mathrm{mM})$, $0.8 \mu \mathrm{L}(20 \mu \mathrm{g} / \mu \mathrm{L})$ of bovine serum albumin (BSA), $0.3 \mu \mathrm{L}(5 \mathrm{U} / \mu \mathrm{L})$ of Roche Taq DNA Polymerase, $0.8 \mu \mathrm{L}(10 \mathrm{mM})$ of each primer, and $1 \mu \mathrm{L}$ of template DNA, and following a thermocycling profile of 5 min at $95^{\circ} \mathrm{C}$; followed by 35 cycles of $30 \mathrm{~s}$ at $94{ }^{\circ} \mathrm{C}, 45 \mathrm{~s}$ at $57-50{ }^{\circ} \mathrm{C}$, and $90 \mathrm{~s}$ at $72{ }^{\circ} \mathrm{C}$; and a final extension for $10 \mathrm{~min}$ at $72{ }^{\circ} \mathrm{C}$. The amplified PCR products were checked in $1 \%$ agarose gel under UV light and quantified on NanoDrop ${ }^{\circledR}$. Sanger sequencing was performed bi-directionally at in-house facilities (Servizio di Biologia Molecolare RIMAR, SZN) on a Thermo Fisher Scientific 48 capillary ABI 3730xl DNA Analyzer, using 4.5 micromolar of each of the corresponding PCR primer pairs, and 15 femtomoles/uL of DNA template. Chromatograms of forward and reverse reads were visualized, assembled, and corrected on Geneious Prime ${ }^{\circledR} 2020.1 .1$ http://www.geneious.com [25], and poriferan origin was checked by BLAST against NCBI GenBank (http://www.ncbi.nlm.nih.gov/BLAST/ [26]. All the sequences in this study were retrieved from a single specimen and have been deposited, along with the morphological descriptions, in GenBank (accession numbers: MT176773 and MT177208) and Sponge Barcoding Project databases for public access.

\subsection{Genetic Analysis}

Reference sequences for the two markers, COI and ITSs, from sponges in the Family Spongillidae (including all the available entries for Genus Spongilla), along with two outgroup demosponges Echinospongilla brichardi (Brien, 1974) and Oncosclera sp. in the Order Spongillida, were downloaded from Genbank for phylogenetic approaches (Table S1 in the Supplementary Materials for accession numbers of reference sequences). The resulting data set was aligned against our sequences with MAFFT (Multiple Alignment using Fast Fourier Transform) [27] under default settings in Geneious Prime ${ }^{\circledR}$ 2020.1.1 [25]. COI alignments were checked by amino acid translation. GBlocks 0.91b was applied to identify and exclude poorly aligned blocks with large gap positions variability in the ITSs alignment. The program was run with stringent settings via the web interface (http: //phylogeny.lirmm.fr/phylo_cgi/one_task.cgi?task_type=gblocks) [28]. Curated ITS alignments from GBlocks were then used for downstream analyses. For each marker separately, and for the concatenated alignment, COI-ITSs Maximum Likelihood (ML) trees were built on IQTree with 1500 ultrafast bootstrap replicates [29] under the most fitting genetic models by partitions according to ModelFinder [30], i.e., $\mathrm{TPM} 3 \mathrm{u}+\mathrm{F}+\mathrm{I}$ for $\mathrm{COI}$ and TPM2+F+G4 for ITSs. Concatenated data returned the most informative outcomes and, hence, was further used for Bayesian analysis (BA) and tree construction on MrBayes [31] with GTR GAMMA model and Markov Chain Monte Carlo (MCMC) set for 1,100,000 generations, 4 chains, 200 generations sampling frequency, and 500 burnin values. All the phylogenetic analytic tools were run on the CIPRES web portal (http://www.phylo.org/) [32].

To estimate species delimitation, two methods were applied: the Automatic Barcode Gap Discovery (ABGD) based on barcode gap [33] and the Poisson-Tree-Processes (PTP), which relies on branch lengths representing the number of substitutions in a phylogenetic tree [34]. The ABGD analysis was performed on our alignments through the server (www.abi.snv.jussieu.fr/public/abgd/) with parameters 
set to genetic model Kimura (K80) TS/TV 2.0 and 1.5 relative gap width. For bPTP method, the above ML trees from IQTree (with their corresponding substitution models by partition) were used as inputs on the webserver (https://species.h-its.org/ptp/).

\section{Results and Discussion}

Marine lakes of this area are not monitored with continuity and historical time series are not available. Information regarding human exploitation of the lakes has been collected through Local Ecological Knowledge (LEK), interviewing some fishermen encountered in the bay. The environmental characteristics of the lake are shown in Table 1 . The salinity reflected remarkably low values, especially during the summer, when monsoon rains are frequent. The temperature showed wide oscillations, escalating in the hot season by over $13^{\circ} \mathrm{C}$ and reaching particular high values on the lake bottom $(\sim 6 \mathrm{~m}$ depth). Such increased temperatures in the lower layers of the lake create the typical condition of solar ponds and could limit in part sponge colonization toward deeper zones.

Table 1. Environmental factors in the Cahong lake measured in winter (December 2017) and summer August 2018).

\begin{tabular}{cc}
\hline 7/12/2017 & $\mathbf{2 1 / 0 8 / 2 0 1 8}$ \\
\hline $\mathrm{S} \%=12$ & $\mathrm{~S} \%=8$ \\
$\mathrm{pH}=7.2$ & $\mathrm{pH}=7.65$ \\
$\mathrm{DO} \mathrm{mg} / \mathrm{L}($ Dissolved Oxygen $)=6.7$ & $\mathrm{DO} \mathrm{mg} / \mathrm{L}($ Dissolved Oxygen $)=5.09$ \\
$\mathrm{~T}=20.7^{\circ} \mathrm{C}$ At the surface & $\mathrm{T}=33.4^{\circ} \mathrm{C}$ At the surface \\
\hline
\end{tabular}

The exploratory transect dives at Cahong Lake revealed a benthic community composed of green algae, conspicuous bivalve aggregations belonging to various species, polychaetes (Owenia sp., Sabellaria sp.) fouling on algal material and other surfaces, and a few small-sized fish. The sponge fauna went down to $3 \mathrm{~m}$ depth and consisted of a single demosponge species (described here) growing on diverse natural (rocks and roots) and anthropogenic artificial substrates (polystyrene material).

\subsection{Taxonomical Account}

Class: Demospongiae Sollas, 1885

Subclass: Heteroscleromorpha Cárdenas, Pérez and Boury-Esnault, 2012

Order: Spongillida Manconi and Pronzato, 2002

Family: Spongillidae Gray, 1867

Genus: Spongilla Lamarck, 1816

Spongilla manconiae Calcinai and Bertolino sp. nov.

urn:lsid:zoobank.org:act:01A112C2-949E-4571-8B3D-7692BE9B66FE

(Figures 2-4)

\subsubsection{Material Examined}

Holotype: MSNG 61501, Cahong, Ha Long Bay, Northern Vietnam, Tonkin Gulf, 21 August 2018, 0-50 cm depth. Paratype: MSNG 61502, Cahong, Ha Long Bay, Northern Vietnam, Tonkin Gulf, 21 August 2018, 0-50 cm depth.

Topotypes: HL108, HL108A, HL108B, HL108C, HL108D. Cahong, Ha Long Bay, Northern Vietnam, Tonkin Gulf 21 August 2018, 0-50 cm depth.

\subsubsection{Species Diagnosis}

Spongilla characterized by creamy-brownish color, smooth oxeas, and spiny microxeas typically with bouquets of spines in the central part and triangular spines on the distal parts. Gemmuloscleres are spined oxeas. 


\subsubsection{Description}

Thickly encrusting with ridges, grooves, and erect processes up to $3 \mathrm{~cm}$ high, with apical oscula. The surface is uneven and irregular. A translucent, thin dermal membrane is detectable especially over the processes and the oscula. Consistency is fragile and soft. The color is creamy/brownish in life and brown in dry state (Figure 2a-c). Some specimens were filled with gemmules.

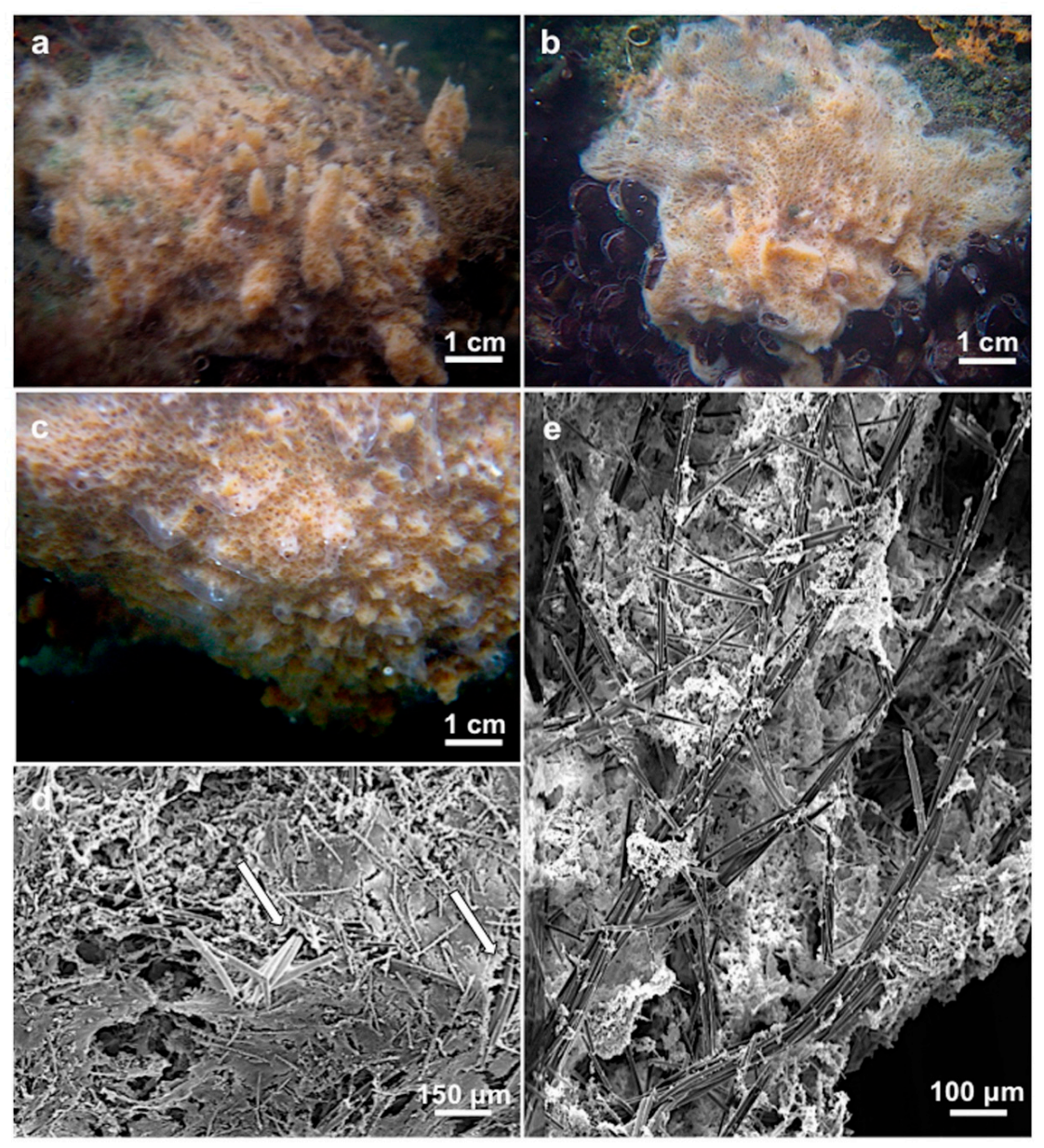

Figure 2. Spongilla manconiae sp. nov. (a) Holotype MSNG 61501; (b) Paratype MSNG 61502; (c) Topotype HL108; (d) Ectosomal skeleton with tangential spiny microxeas. Arrows indicate the spicules of the longitudinal primary fibers that protrude from the sponge surface; (e) Choanosomal skeletal architecture (transverse section).

The holotype consists of three fragments of about $3 \times 1.5 \times 1 \mathrm{~cm}, 2 \times 1 \mathrm{~cm}$ and $4 \mathrm{~mm}$ thick and $1 \times 1 \mathrm{~cm}$ and $3 \mathrm{~mm}$ in thickness. The paratype consists of two portions of about $3 \times 2 \times 2$ and $2 \times 1 \times 1 \mathrm{~cm}$, growing under a piece of polystyrene floating in the lake (Figure 3a). Other specimens covered areas up to $100 \mathrm{~cm}^{2}$. Ectosomal skeleton consists of spiny microxeas tangentially arranged (Figure 2d). Choanosomal skeleton is an irregular, paucispicular, anisotropic reticulation; longitudinal primary fibers run toward the sponge surface (Figure 2e). Megascleres are oxeas slightly curved, smooth, and with acerate tips (Figure 4a). Numerous thinner oxeas are considered forms of growth (measurements in Table 2). Microscleres are spiny microxeas (Figure 4b). At their extremities, they are covered by hooked spines bent toward the shaft. At the center of the spicule, axis spines are grouped in bouquets (measurements in Table 2). 

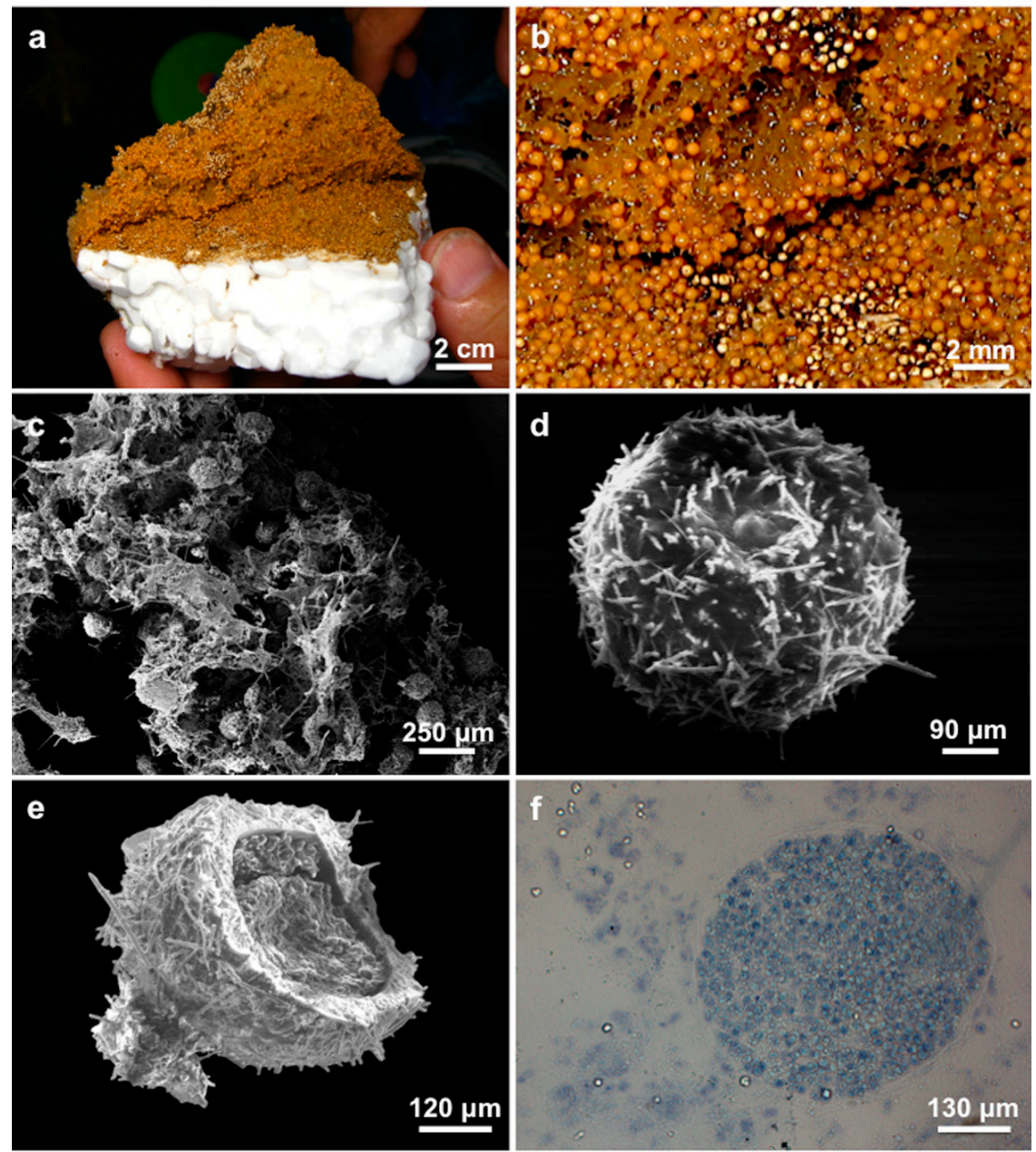

Figure 3. Spongilla manconiae sp. nov. (a) Paratype MSNG 61502 grown under a piece of polystyrene floating in the lake; (b) Magnification of the gemmules; (c) SEM image of the gemmules; (d) Gemmule with a single foramen; (e) Section of a gemmule, with a simple, monolayered theca, armored by a layer of tangential gemmuloscleres; (f) Histological section of a gemmule.

Table 2. Spicule dimensions of the examined specimens. The "** indicates the absence or scarcity of spicules in the preparation due to the lack of gemmules.

\begin{tabular}{|c|c|c|c|}
\hline Specimens & Oxeas $(\mu \mathrm{m})$ & Microxeas $(\mu \mathrm{m})$ & Gemmuloscleres $(\mu \mathrm{m})$ \\
\hline $\begin{array}{l}\text { MSNG } 61501 \\
\text { holotype }\end{array}$ & $\begin{array}{c}205(272.5 \pm 28.4) 332.1 \times 8.2 \\
(11.8 \pm 3.2) 16.4\end{array}$ & $\begin{array}{c}80.6(103.59 \pm 18.5) 161.2 \times 1.3 \\
(2.08 \pm 0.6) 2.6\end{array}$ & $78(97.85 \pm 8.8) 111.8 \times 7.8$ \\
\hline $\begin{array}{l}\text { MSNG } 61502 \\
\text { paratype }\end{array}$ & $255(291.1 \pm 23.8) 350 \times 10$ & $75(94.3 \pm 12.7) 112.5 \times 2.5$ & $87.5(100.4 \pm 11.9) 124 \times 5$ \\
\hline $\begin{array}{l}\text { HL } 108 \\
\text { topotype }\end{array}$ & $\begin{array}{c}255(283.5 \pm 19.1) 310 \times 7.5(8.9 \pm \\
1.5) 11.25\end{array}$ & $80(103.6 \pm 11.4) 120 \times 2.5$ & $82.5(101.8 \pm 9) 115 \times 5$ \\
\hline $\begin{array}{l}\text { HL108A } \\
\text { topotype }\end{array}$ & $\begin{array}{c}260(308 \pm 26.3) 345 \times 6.2(8.9 \pm 1.5) \\
10\end{array}$ & $82.5(107.1 \pm 111.4) 122.5 \times 2.5$ & $*$ \\
\hline $\begin{array}{l}\text { HL108B } \\
\text { topotype }\end{array}$ & $275(306 \pm 16.4) 340 \times 7.5$ & $67.5(94.8 \pm 13.3) 110 \times 2.5$ & $100-105 *$ \\
\hline $\begin{array}{l}\text { HL108C } \\
\text { topotype }\end{array}$ & $\begin{array}{c}260(282 \pm 17.2) 320 \times 6.2(8.5 \pm 1.6) \\
10\end{array}$ & $90(103.2 \pm 9.1) 122.5 \times 2.5$ & * \\
\hline $\begin{array}{l}\text { HL108D } \\
\text { topotype }\end{array}$ & $\begin{array}{c}280(311 \pm 14.4) 340 \times 7.5(8.2 \pm 1.1) \\
10\end{array}$ & $77.5(101.5 \pm 15.3) 125 \times 2.5$ & $75(96.9 \pm 11) 120 \times 5$ \\
\hline
\end{tabular}




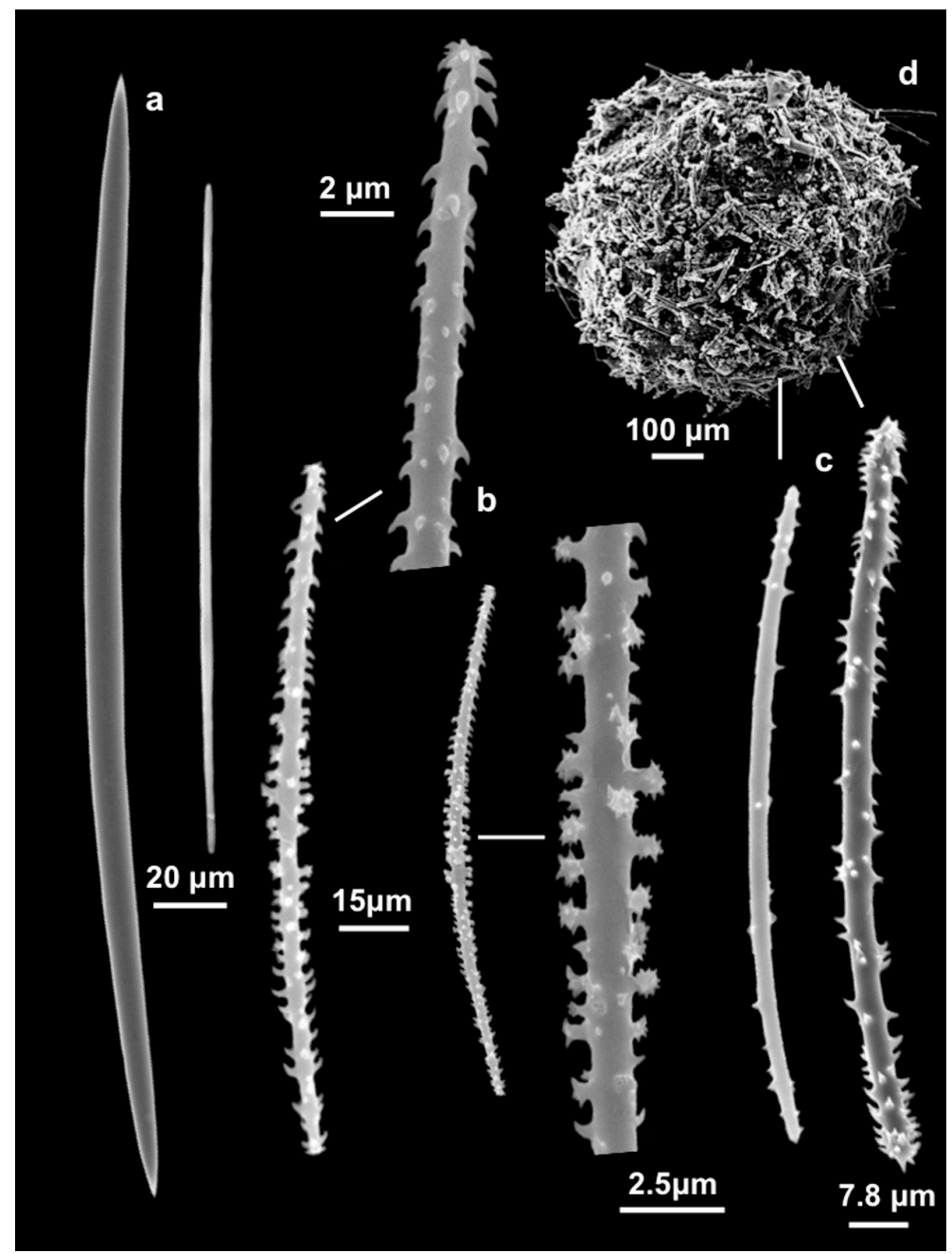

Figure 4. Spongilla manconiae sp. nov. SEM images of spicules. (a) Oxeas; (b) Microxeas, with magnification of the spines; (c) Gemmuloscleres; (d) Gemmule.

Gemmules are of a single type; they are abundant and scattered in the tissue, are about $500 \mu \mathrm{m}$ in diameter, and are covered by a simple, monolayered theca, armored with a layer of tangential gemmuloscleres (Figure 3a-f). A single foramen was observed (Figure 3d). Gemmuloscleres (Figure 4c) are spined oxeas with triangular spines, more concentrated at the distal part (measurements in Table 2).

\subsubsection{Habitat and Distribution}

Covering large areas of substrate at low depth. Known from Hồ Cá Hồng (Cahong), Ha Long Bay, Tonkin Gulf, $20^{\circ} 52^{\prime} 41^{\prime \prime} \mathrm{N}-107^{\circ} 12^{\prime} 1^{\prime \prime}$ E.

\subsubsection{Etymology}

This new species is named after Dr. Renata Manconi (Dipartimento di Medicina Veternaria-Università degli Studi di Sassari) in recognition of her relevant contribution to taxonomic studies on freshwater sponges.

\subsubsection{Remarks}

The species is assigned to the genus Spongilla because of the presence of smooth oxeas, spiny microxeas, and spiny oxeas as gemmuloscleres. Gemmules are distributed in dense clusters or scattered, with a mono-layered gemmular theca and a simple foramen. 
Fifteen species belonging to Spongilla are known [24], but one of them, Spongilla friabilis, Lamarck (1816) was insufficiently described without any information about spicules, making difficult any comparison (Table 3): "Sp. sessilis, convexa, obsoletè lobulata, intùts fibrosa; fibris longitudinalibus, ramuloso-cancellatis. Spongia friabilis. Esper. suppl. tab. 62. Habite dans les étangs. Elle est granifère, et n'a presque point de parenchyme entre ses fibres" [35]. Some authors [24] point out that this species, described by Lamarck, could be a junior homonym of Spongia friabilis Linnaeus, 1788 from the Bodensee lake (Germany) and, therefore, is considered as taxon inquirendum.

Table 3. Comparison of the spicule dimensions of Spongilla manconiae sp. nov. with the other known Spongilla species. Geographical distributions were checked in the World Porifera Data Base [24].

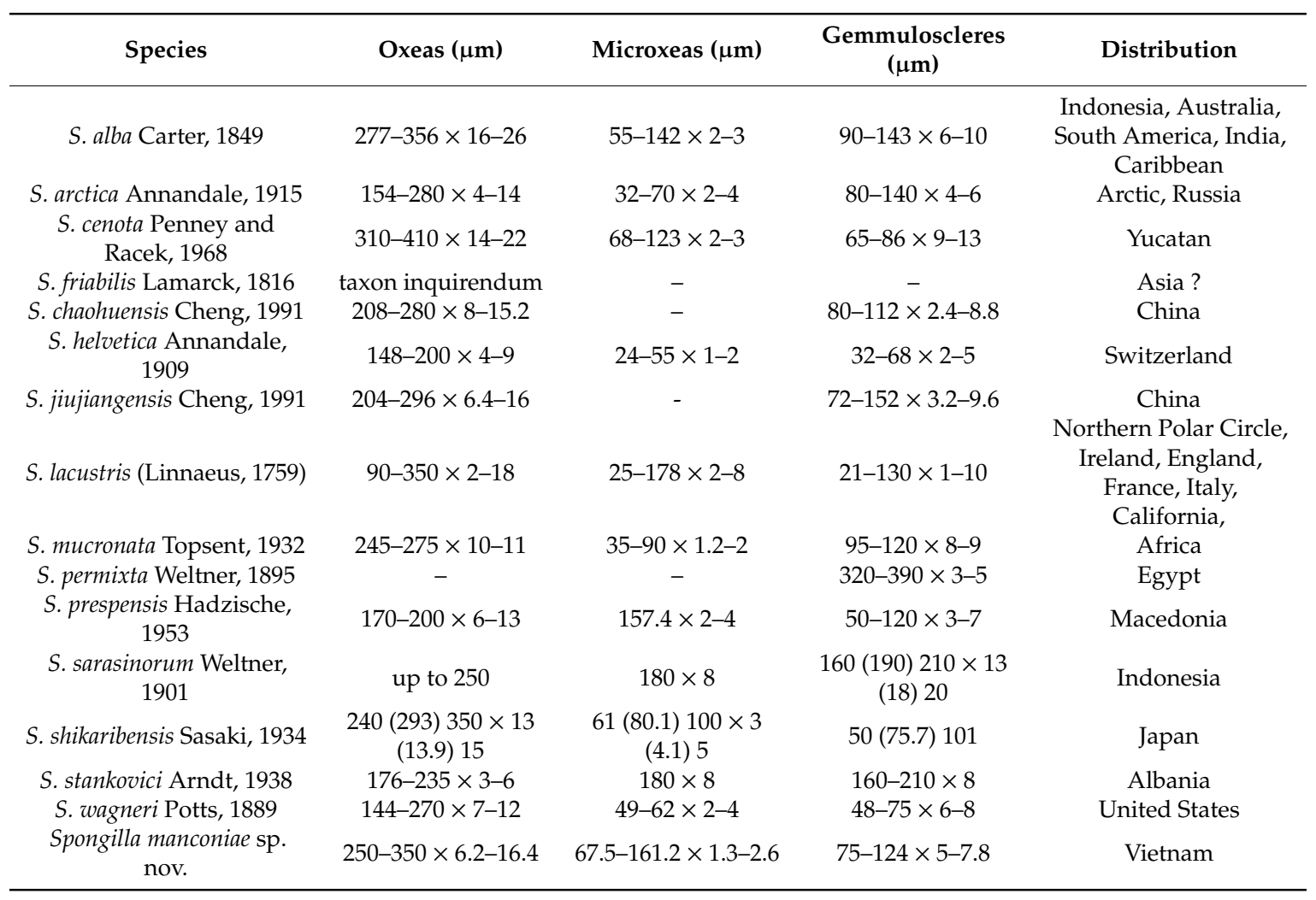

The species of the genus Spongilla described in geographical areas, next to Vietnam, are five: S. alba, S. chaohuensis, S. jiujiangensis, S. sarasinorum, and S. shikaribensis; they differ from S. manconiae for their spicular complements and shape and size of the spicules (Table 3). Among these, S. chaohuensis, Cheng, 1991, from China, is the only one close to the new species. Cheng's publication is in Chinese, and the translated basic parts are reported below: "Several specimens of flat sponge. With digits, channels, and cavities. Large, circular oscula, slightly raised. Color in dry state from light green on the surface to dark ash in the inner part. Structure: fine and compact skeletal composition, radial shape of the fibers not evident, a large number of horizontal fibers form a very fine skeletal network. It has a lichenoid type surface".

Spongilla chaohuensis, Cheng, 1991 lacks spined microxeas (Table 3) and its spicules are smaller than in S. manconiae. The latter, therefore, has to be considered as a new species for science.

\subsection{Genotyping}

The concatenated fragment obtained from integrating the COI Folmer (613 bp) and Erpenbeck (561 bp) partitions was $1036 \mathrm{bp}$ long, whereas the ITSs region spanned $861 \mathrm{bp}$. Phylogenetic analyses were largely hampered due to the scarce representation of Spongilla spp. in the reference databases. Fourteen COI sequences, 12 of S. lacustris (from Russia, India, Germany, and Ireland) and two 
of S. vastus (from Indonesia), and 12 ITSs sequences, all from S. lacustris (from Russia, Germany, Bosnia-Herzegovina, and the USA.), were the only reference sequencing data available to build congeneric alignments for both markers (Supplementary Table S1). GBlocks curated ITSs alignments retained $373 \mathrm{bp}$ for the set of Spongilla sequences and $300 \mathrm{bp}$ for the larger set comprising the family Spongillidae. When accounting for the number of variable nucleotide sites in the sequences of the new Spongilla manconiae against reference congeneric sequences, the COI alignment revealed $13-20(2-3 \%)$ variable sites against $S$. lacustris and $S$. vastus. A much larger proportion of consistent informative variable sites was found in the ITSs against S. lacustris entries $(110-111,30 \%)$. This supports the already proposed higher resolution potential of the nuclear ITS with respect to COI for freshwater sponges [36,37]. BLAST searches matched the non-curated ITS from S. manconiae with S. lacustris entries. Instead, the closest match for COI did not correspond to any Spongilla (S. lacustris or S. vastus) but to a Corvospongilla ultima from Myanmar, which differed from our sequence by 10 nucleotides. These results further advocate a low taxonomical (intra- and intergeneric) resolution of COI and uphold the need to combine several genetic markers for resolving certain Porifera groups [22,36,38].

Species delimitation analyses based on ABGD and PTP for each of the two markers separated S. manconiae from other Spongilla. This was an expected outcome, as reference sequences came from geographically distant specimens, with divergent morphologies (see Table 3). PTP delimitation for the COI marker afforded coherent clustering for S. vastus but was inconsistent within S. lacustris. In particular, two conspecifics coming from India and two from Russia were grouped out of the major cluster. For the ITSs data instead, all S. lacustris formed a single cluster separated from S. manconiae. Intra- and interspecific dissimilarity based on ABGD for the COI marker revealed distances ranging $0-0.7 \%$ within the reference Spongilla sequences, and $1.3-1.9 \%$ between any congeneric entry against $S$. manconiae. Instead, for the curated ITSs gene, distances ranged 0-0.7\% within S. lacustris, while the interspecific distance against S. manconiae was $32 \%$. Across the family Spongillidae, ABGD distances spanned $0.7-2.8 \%$ with the COI and $12-49 \%$ with the ITSs. Once more dissimilarities based on COI revealed low taxonomical resolution across genera, with values below the universal threshold consensus of $0.3 \%$ genetic distance for species delimitation [22,36,38].

Phylogenetic ML and BI trees on family Spongillidae with either concatenated (COI-ITS) or non-concatenated (separate COI and ITSs, results not shown) data could not recover Genus Spongilla as monophyletic (Figures 5 and 6). Spongillidae, which is the most specious freshwater family and with a high incidence of endemism, is recognized in earlier molecular studies as non-monophyletic [37,39]. On what regards Spongilla, the description of the genus is rather ample, e.g., with only some species containing gemmular cages made of megascleres, gemmules may be without or with gemmuloscleres, gemmules may have a single or multiple foramina. Out of the 14 accepted species (15 with the present record, and not considering Spongilla friabilis), only two are represented as sequencing entries, suggesting that further genetic work to repopulate public databases is required to corroborate the non-monophyly of this taxon. In this particular study, some of the observed noise on tree topologies was likely induced by the two Indian and two Russian discordant S. lacustris mentioned above. Spongilla manconiae was placed alone on a very long branch in the phylogenetic trees, close to its congeneric group, and clustered with Corvospongilla ultima (see Figures 5 and 6). This clustering is probably an artifact resulting from the long-branch attraction, again due to a deficient amount of congeneric sequencing reference data, and low COI resolution. C. ultima (originally described as Spongilla ultima) is morphologically different (e.g., microscleres are smooth or spined micropseudobirotules, megascleres may be smooth or granulated strongyles or oxeas). Moreover, it is exclusively a freshwater species, never reported from brackish systems [40]. 


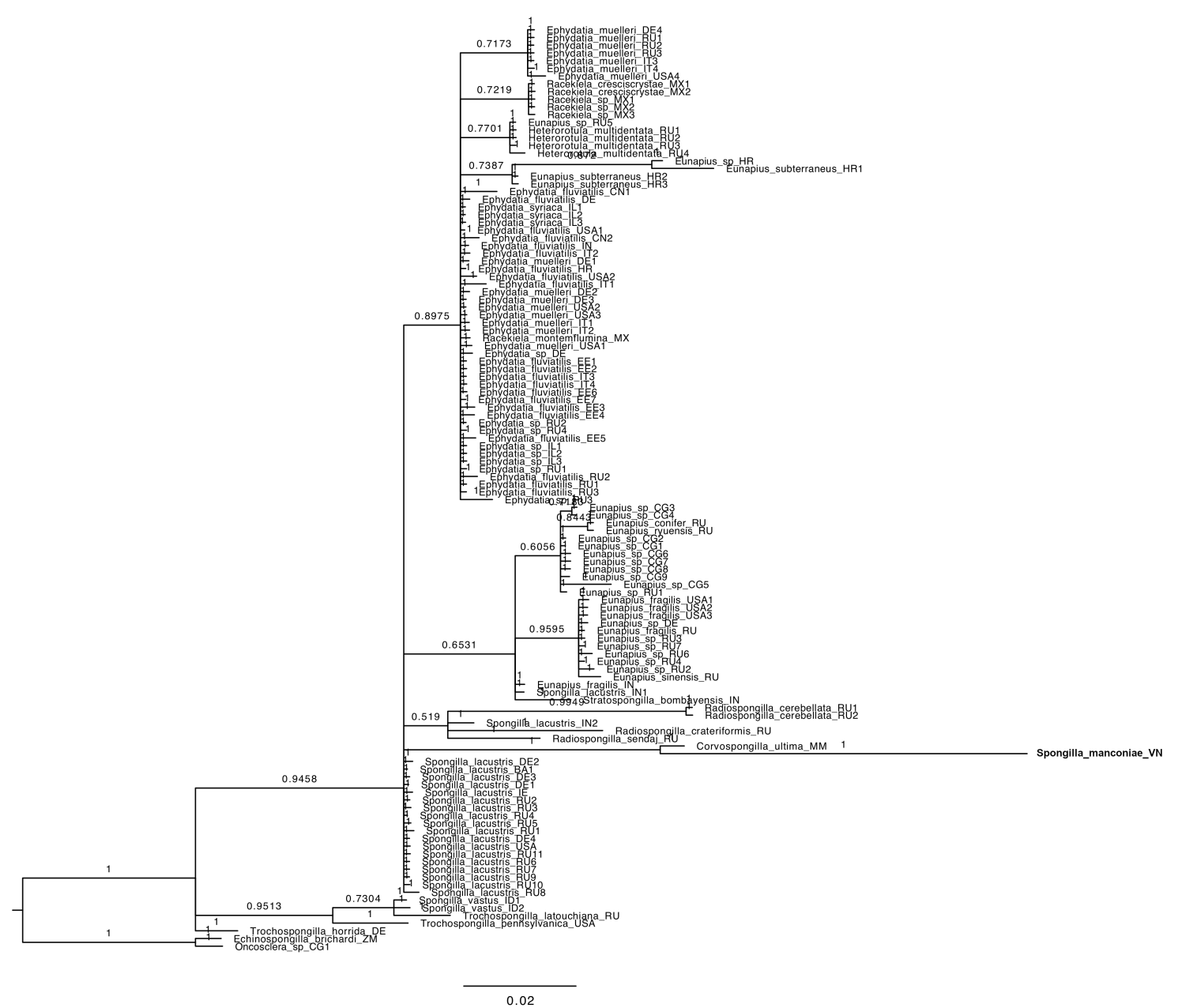

Figure 5. Bayesian inference (BI) phylogenetic tree, applying the concatenated data set of the Cytochrome C Oxidase subunit 1 (COI) and curated ITSs, with the posterior probabilities shown at each node. The analysis was built with the newly described sponge, Spongilla manconiae sp. nov., along with a representative suite of reference sequences in the Spongillidae Family plus two outgroup entries (Echinospongilla bichardi, and Oncosclera sp.) downloaded from the GenBank database. The country codes and Accession numbers can be found in Supplementary Table S1.

The new species is the first record of Spongilla in Vietnam, adverting a certain level of endemism, and likely genetic and consequent phenotypic diversification. Indeed, the morphological characteristics, the branch length topology in the phylogenetic trees, and the genetic distances recorded for the new S. manconiae drive us to suggest two things. On the one hand, they highlight a gap in the reference set of taxonomically related sequences from nearby geographic areas. On the other hand, it implies a process of accelerated evolution (and reflexed in the studied loci), likely driven by the extreme and unique environmental conditions in the enclosed lake. Rapid radiation processes, involving genetic, morphofunctional, and anatomical adaptations, seem to be a common trend in habitants of ancient lakes [5]. In the light of our results, we emphasize the role of enclosed marine lakes as motors of accelerated speciation and their relevance to study evolution and adaptation processes. 




Figure 6. Maximum likelihood phylogenetic tree applying the concatenated data set of COI and curated ITSs, with the bootstrap values shown at each node. The analysis was built with the newly described sponge, Spongilla manconiae sp. nov., along with a representative suite of reference sequences in the Spongillidae Family plus two outgroup entries (Echinospongilla bichardi and Oncosclera sp.) downloaded from the GenBank database. The country codes and Accession numbers can be found in Supplementary Table S1.

Supplementary Materials: The following is available online at http://www.mdpi.com/2077-1312/8/12/1008/s1, Table S1: Reference sequences downloaded from GenBank database for COI marker gene of sponge species in the Family Spongillidae, plus Echinospongilla.

Author Contributions: B.C., M.P., and M.B. cooperated in the field and did the morphological work. B.C. and M.B wrote the species descriptions. C.C. coordinated the fieldwork, performed the sampling, and drafted the manuscript. L.N.-P. performed the DNA analyses and drafted the manuscript. D.C.T. coordinated and cooperated in the fieldwork. All authors have read and agreed to the published version of the manuscript.

Funding: This paper is the result of a state research project for international cooperation KC09.11/16-20 "Study on biodiversity of limestone islands and limestone archipelagos in Vietnam's waters; propose solutions and models for use and protection, survival and sustainable development" and project cod NVCC 23.02/20-20 that provided support for the research.

Acknowledgments: The authors would like to thank F. Rispo and V. Mazzella for laboratory work and J. Moles for analytical advice.

Conflicts of Interest: The authors declare that they have no conflict of interest.

\section{References}

1. Thung, D.G.; Ngai, N.D.; Sinh, N.V.; Quan, N.V.; Tien, D.D.; Thuoc, C.V.; Trang, C.T.T. Biodiversity of Limestone Island and Archipelagos Areas in Northeast Coast of Vietnam, Orientation of Sustainable Use Solutions; Publishing House of Natural Science and Technology: Ha Noi, Vietnam, 2018; pp. 56-57. (In Vietnamese) 
2. Vermeulen, J.J.; Anker, K. Outstanding global values in geology and environment in Cat Ba archipelago and Halong Bay. In Proceedings of the Biodiversity Conservation Solutions in Ha Long bay and Cat Ba Archipelago, IUCN, Haiphong City, Vietnam, 24 August 2017; pp. 16-23.

3. Cerrano, C.; Azzini, F.; Bavestrello, G.; Calcinai, B.; Pansini, M.; Sarti, M.; Thung, D.C. Marine lakes of karst islands in the Ha Long Bay (Vietnam). Chem. Ecol. 2006, 22, 489-500. [CrossRef]

4. Becking, L.E.; Renema, W.; Santodomingo, N.K.; Hoeksema, B.W.; Tuti, Y.; de Voogd, N.J. Recently discovered landlocked basins in Indonesia reveal high habitat diversity in anchialine systems. Hydrobiologia 2011, 677, 89-105. [CrossRef]

5. Dawson, M.; Hamner, W.N. Rapid evolutionary radiation of marine zooplankton in peripheral environments. Proc. Natl. Acad. Sci. USA 2005, 102, 9235-9240. [CrossRef]

6. Cerrano, C.; Bavestrello, G.; Calcinai, B.; Cattaneo-Vietti, V.; Chiantore, M.; Guidetti, M.; Sarà, A. Bioerosive processes in Antarctic seas. Pol. Biol. 2001, 24, 790-792. [CrossRef]

7. Díaz, M.C.; Rützler, K. Sponges: An essential component of Caribbean coral reefs. Bull. Mar. Sci. 2001, 69, 535-546.

8. Bertolino, M.; Cerrano, C.; Bavestrello, G.; Carella, M.; Pansini, M.; Calcinai, B. Diversity of Porifera in the Mediterranean coralligenous accretions, with description of a new species. Zookeys 2013, 336, 1-37. [CrossRef]

9. Gerovasileiou, V.; Voultsiadou, E. Sponge diversity gradients in marine caves of the eastern Mediterranean. J. Mar. Biol. Assoc. UK 2016, 96, 407-416. [CrossRef]

10. Wulff, J.L. Ecological interactions of marine sponges. Can. J. Zool. 2006, 84, 146-166. [CrossRef]

11. Becerro, M.A. Quantitative trends in sponge ecology research. Mar. Ecol. 2008, 29, 167-177. [CrossRef]

12. Azzini, F.; Calcinai, B.; Cerrano, C.; Bavestrello, G.; Pansini, M. Sponges of the marine karst lakes and of the coast of the islands of Ha Long Bay (North Vietnam). In Porifera Research: Biodiversity, Innovation and Sustainability; Custódio, M.R., Lôbo-Hajdu, G., Hajdu, E., Muricy, G., Eds.; Museu National Rio de Janeiro: Rio de Janeiro, Brazil, 2007; pp. 157-164.

13. Quang, T.M. A review of the diversity of sponges (Porifera) in Vietnam. In Proceedings of the 2nd International Workshop on Marine Bioresources of Vietnam, Hanoi, Vietnam, 5-6 June 2013; pp. 109-115.

14. Calcinai, B.; Azzini, F.; Bavestrello, G.; Cerrano, C.; Pansini, M.; Thung, D.C. Boring Sponges from Ha Long Bay, Tonkin Gulf, Vietnam. Zool. Stud. 2006, 45, 201-212.

15. Cerrano, C.; Bavestrello, G.; Bertolino, M.; Pansini, M.; Núñez-Pons, L.; Sarti, M.; Thung, D.C.; Calcinai, C. The Ha Long Bay marine ecosystem. An unprecedented opportunity for evolutionary studies on marine taxa. In Innovations in Land, Water and Energy for Vietnam's Sustainable Development; Anderle, M., Ed.; Unipa Springer Series; Springer: Cham, Switzerland, 2021; pp. 45-52. [CrossRef]

16. Fenart, N.; Cat, N.; Drogue, C.; Van Canh, D.; Pistre, S. Influence of tectonics and neotectonics on the morphogenesis of the peak karst of Halong Bay, Vietnam. Geodin. Acta 1999, 12, 193-200. [CrossRef]

17. Egi, S.M.; Cousteau, P.Y.; Pieri, M.; Cerrano, C.; Özyigit, T.; Marroni, A. Designing a Diving Protocol for Thermocline Identification Using Dive Computers in Marine Citizen Science. Appl. Sci. 2018, 8, 2315. [CrossRef]

18. Rützler, K. Sponges in coral reefs. In Coral Reefs: Research Methods. Monographs on Oceanografic Methodologies; Stoddart, D.R., Johannes, R.E., Eds.; UNESCO: Paris, France, 1978; Volume 5.

19. Hooper, J.N.A. 'Sponguide'. Guide to Sponge Collection and Identification. 2000. Available online: http://www.qm.qld.gov.au/organisation/sections/SessileMarineInvertebrates/spong.pdf (accessed on 1 May 2020).

20. Folmer, O.; Black, M.; Hoeh, W.; Lutz, R.; Vrijenhoek, R. DNA primers for amplification of mitochondrial cytochrome c oxidase subunit I from diverse metazoan invertebrates. Mol. Mar. Biol. Biot. 1994, 3, $294-299$.

21. Xavier, J.R.; Rachello-Dolmen, P.G.; Parra-Velandia, F.; Schönberg, C.H.L.; Breeuwer, J.J.; Van Soest, R.W.M. Molecular evidence of cryptic speciation in the "cosmopolitan" excavating sponge Cliona celata (Porifera, Clionaidae). Mol. Phylog. Evol. 2010, 56, 13-20. [CrossRef]

22. Erpenbeck, D.; Hooper, J.N.A.; Wörheide, G. CO1 phylogenies in diploblasts and the 'Barcoding of Life'—are we sequencing a suboptimal partition? Mol. Ecol. Notes 2006, 6, 550-553. [CrossRef]

23. Wörheide, G.; Nichols, S.; Goldberg, J. Intragenomic variation of the rDNA internal transcribed spacers in sponges (Phylum Porifera): Implications for phylogenetic studies. Mol. Phylogenet. Evol. 2004, 33, 816-830. [CrossRef] [PubMed] 
24. Van Soest, R.W.M.; Boury-Esnault, N.; Hooper, J.N.A.; Rützler, K.; de Voogd, N.J.; Alvarez, B.; Hajdu, E.A.; Pisera, B.; Manconi, R.; Schönberg, C.; et al. World Porifera Database. 2020. Available online: http: //www.marinespecies.org/porifera (accessed on 20 November 2020).

25. Kearse, M.; Moir, R.; Wilson, A.; Stones-Havas, S.; Cheung, M.; Sturrock, S.; Buxton, S.; Cooper, A.; Markowitz, S.; Duran, C.; et al. Geneious basic: An integrated and extendable desktop software platform for the organization and analysis of sequence data. Bioinformatics 2012, 28, 1647-1649. [CrossRef]

26. Altschul, S.F.; Madden, T.L.; Schaffer, A.A.; Zhang, J.; Zhang, Z.; Miller, W.; Lipmann, D.J. Gapped BLAST and PSI- BLAST: A new generation of protein database search programs. Nucleic Acids Res. 1997, 25, 3389-3402. [CrossRef]

27. Katoh, K.; Standley, D.M. MAFFT multiple sequence alignment software version 7: Improvements in performance and usability. Mol. Biol. Evol. 2013, 30, 772-780. [CrossRef]

28. Castresana, J. Selection of conserved blocks from multiple alignments for their use in phylogenetic analysis. Mol. Biol. Evol. 2000, 17, 540-552. [CrossRef]

29. Nguyen, L.T.; Schmidt, H.A.; von Haeseler, A.; Minh, B.Q. IQ-TREE: A fast and effective stochastic algorithm for estimating maximum likelihood phylogenies. Mol. Biol. Evol. 2015, 32, 268-274. [CrossRef] [PubMed]

30. Kalyaanamoorthy, S.; Minh, S.Q.; Wong, T.K.F.; von Haeseler, A.; Jermiin, L.S. Model Finder: Fast Model Selection for Accurate Phylogenetic Estimates. Nat. Methods 2017, 14, 587-589. [CrossRef] [PubMed]

31. Ronquist, F.; Teslenko, M.; van der Mark, P.; Ayres, D.L.; Darling, A.; Höhna, S.; Larget, B.; Liu, L.; Suchard, M.A.; Huelsenbeck, J.P. MRBAYES 3.2: Efficient Bayesian phylogenetic inference and model selection across a large model space. Syst. Biol. 2012, 61, 539-542. [CrossRef] [PubMed]

32. Miller, M.A.; Pfeiffer, W.; Schwartz, T. Creating the CIPRES science gateway for inference of large phylogenetic trees. In Proceedings of the Gateway Computing Environments Workshop (GCE), New Orleans, LA, USA, 14 November 2010; IEEE: Piscataway, NJ, USA, 2010; pp. 1-8.

33. Puillandre, N.; Lambert, A.; Brouillet, S.; Achaz, G. ABGD, Automatic Barcode Gap Discovery for primary species delimitation. Mol. Ecol. 2012, 21, 1864-1877. [CrossRef] [PubMed]

34. Zhang, J.; Kapli, P.; Pavlidis, P.; Stamatakis, A. A general species delimitation method with applications to phylogenetic placements. Bioinformatics 2013, 29, 2869-2876. [CrossRef]

35. De Lamarck, J.B.D.M. Histoire Naturelle Des Animaux Sans Vertèbres; Verdière: Paris, France, 1816; tome second; p. 568.

36. Núñez-Pons, L.; Calcinai, B.; Gates, R.D. Who's there?-First morphological and DNA barcoding catalogue of the shallow Hawai'ian sponge fauna. PLoS ONE 2017, 12, e0189357. [CrossRef]

37. Itskovich, V.; Gontcharov, A.; Masuda, Y.; Nohno, T.; Belikov, S.; Efremova, S.; Meixner, M.; Janussen, D. Ribosomal ITS sequences allow resolution of freshwater sponge phylogeny with alignments guided by secondary structure prediction. J. Mol. Evol. 2008, 67, 608-620. [CrossRef]

38. Huang, D.; Meier, R.; Todd, P.A.; Chou, M. Slow Mitochondrial COI Sequence Evolution at the Base of the Metazoan Tree and Its Implications for DNA Barcoding. J. Mol. Evol. 2008, 66, 167-174. [CrossRef]

39. Erpenbeck, D.; Steiner, M.; Schuster, A.; Genner, M.; Manconi, R.; Pronzato, R.; Ruthensteiner, B.; Spiegel, D.; Van Soest, R.W.M.; Wörheide, G. Minimalist barcodes for sponges-A case study classifying African freshwater Spongillida. Genome 2018, 62, 1-10. [CrossRef]

40. Jakhalekar, S.S.; Ghate, H.V. Taxonomy of freshwater sponges of Maharashtra, India, with illustrated descriptions and notes on ecology and habitats (Porifera: Spongillida: Spongillidae). Zootaxa 2016, 4173, 501-529. [CrossRef] [PubMed]

Publisher's Note: MDPI stays neutral with regard to jurisdictional claims in published maps and institutional affiliations.

(C) 2020 by the authors. Licensee MDPI, Basel, Switzerland. This article is an open access article distributed under the terms and conditions of the Creative Commons Attribution (CC BY) license (http://creativecommons.org/licenses/by/4.0/). 